\title{
A ÚlTIMA CEIA DO CLUBE DO PICADINHO - UMA ANÁLISE DO LIVRO O CLUBE DOS ANJOS, DE LUIS FERNANDO VERISSIMO
}

\section{THE LAST SUPPER OF THE PICADINHO'S CLUB - AN ANALYSIS OF THE BOOK O CLUBE DOS ANJOS BY LUIS FERNANDO VERÍSSIMO}

Carolina Veloso"

Resumo: O presente artigo apresenta uma perspectiva da Literatura do Rio Grande do Sul desprendida de regionalismos, a exemplo do mito do gaúcho, e mais direcionada para mitos e temas universais. Buscou-se fazer uma breve leitura do livro O Clube dos anjos (1998), de autoria do porto-alegrense Luis Fernando Verissimo, a partir das teorias do imaginário desenvolvidas por Gilbert Durand. A análise restringe-se aos elementos bíblicos presentes na referida obra e, principalmente, à profanação do rito da Última Ceia cristã.

Palavras-chave: Literatura do Rio Grande do Sul; Gilbert Durand; Última Ceia; Mito.

AвSTRACT: This article presents another perspective of the Literature from Rio Grande do Sul, a detached perspective from the regionalism and the Gaucho myth; but focused on myths and universal themes. I attempted to make a brief reading of the book $O$ Clube dos Anjos (1998), authored by porto-alegrense Luis Fernando Verissimo, based on the imaginary theories developed by Gilbert Durand. The analysis was restricted to the biblical elements present in the book, especially the profanation of Christian Last Supper ritual.

KEYwords: Literature from Rio Grande do Sul; Gilbert Durand; Last Supper; Mith.

\footnotetext{
"Doutoranda pelo Programa de Pós-graduação em Literatura da Universidade Federal de Santa Catarina. Mestre em Letras - História da Literatura - pela Universidade Federal do Rio Grande. Email: carolinavelosocosta@gmail.com
} 
Literatura do Rio Grande do Sul - NOTA INTRODUTÓRIA

A Literatura do Rio Grande do Sul durante muito tempo comprometeu-se com temas voltados para o cotidiano regional, destacando-se no sistema literário brasileiro por esse caráter regionalista. Seu início deu-se anteriormente à criação da Sociedade Partenon Literário, a partir de manifestações literárias, que se resumiam basicamente nas poesias do cancioneiro, com temáticas locais e de ambiente revolucionário. Nesse sentido, a importância dessas manifestações literárias foi demasiada por seu valor histórico e pioneiro, ao invés de sua qualidade estética e artística. A literatura do Sul-Rio-grandense consolidou-se com a criação de alguns periódicos, com intuito de abrigar os escritores e divulgar suas produções, como o periódico $O$ Guaíba (1856). (ZILBERMAN, 1992)

A Sociedade Partenon Literário surgiu na segunda metade do século XIX, em meio a grandes inquietações sociais, como a Guerra do Paraguai, o Manifesto Republicano e a luta pela abolição da escravatura, por isso é possível notar que esses temas destacaram-se na maioria dos textos do período. A principal ação da Sociedade no cenário da literatura do Rio Grande do Sul na época deu-se, principalmente, pela criação da Revista Mensal publicada entre os anos 1869 e 1879. A Revista possuía de vinte oito a trinta e duas páginas e preocupava-se em publicar desde contos, novelas, poesias até relatos de discussões desenvolvidas no interior da Sociedade e da cena cultural do período.

O movimento Partenon Literário descentralizou e unificou a literatura gaúcha do período, abordando temáticas que permeavam o regional e o universal, de modo que, conforme destaca Regina Zilberman (1992),

As criações literárias podem ser reunidas em duas grandes vertentes temáticas, ambas decisivas para os estágios ulteriores de nossa cultura: de um lado, apresenta-se a linhagem romântica, explorando os assuntos relacionados à infância, morte e amor desenganado; e, de outro, constata-se a apropriação dos motivos regionais, seja quando da utilização épica do modelo humano rio-grandense oriundo dos pampas, seja enquanto memória do passado glorioso da Província, exaltando-se o índio como matriz do campeiro e a Revolução Farroupilha, marco da História Local. (ZILBERMAN, 1992, p. 14).

De tal forma que, mesmo fora do âmbito ruralista, o gaúcho e suas tradições continuavam sendo a temática principal dos textos literários até a década de 1930. Essa temática destacava-se na literatura do Rio Grande, com presença de escritores como: Simões Lopes Neto (1865 - 1916) e Alcides Maia (1878 - 1944).

Nesse sentido, em meados dos anos 30 (séc. XX), o cenário literário do Rio Grande do $\mathrm{Sul}$ começou a modificar-se, passando priorizar outros temas sociais, como: do campo, do meio urbano e da migração do gaúcho pampeano para os centros urbanos, devido ao processo de industrialização que se sobressaia em todo o país, principalmente nos anos 50 e 60. Já a partir de 1970, a literatura gaúcha vivenciou o "alargamento de seu espectro, incluindo temas inéditos, 
como a exposição e crítica ao processamento de modernização da sociedade, técnicas renovadoras, como o monólogo interior, e personagens até então desconhecidos, como as mulheres" (ZILBERMAN, 1992, p. 130-131). A literatura do sul do Brasil circulou por todo o território nacional e acompanhou o sistema literário brasileiro, ora com marca regionalista, ora livre de qualquer cor local que o restrinja ao território gaúcho.

Dentre as inúmeras temáticas presentes na literatura Sul-Rio-grandense, o fantástico ocupou um espaço de destaque. Pioneiro na literatura fantástica do Rio Grande do Sul, Moacyr Scliar, em 1965, publicou Carnaval dos Animais: uma coletânea/livro com narrativas fantásticas que envolvem desde temáticas sociais a temas que vão além da realidade. Visto que o fantástico implica em um acontecimento que não se pode explicar racionalmente, ou seja, foge da realidade. De acordo com Todorov na escrita fantástica

produz-se um acontecimento que não pode ser explicado pelas leis deste mesmo mundo familiar. Aquele que o percebe deve optar por uma das duas soluções possíveis; ou se trata de uma ilusão dos sentidos, de um produto da imaginação e nesse caso as leis do mundo continuam a ser o que são; ou então o acontecimento realmente ocorreu, é parte integrante da realidade, mas nesse caso esta realidade é regida por leis desconhecidas para nós. (TODOROV, 1975, p. 30).

Dessa maneira, o fantástico é aquilo que fica no âmbito da dúvida e deixa a incerteza sobre a verossimilhança dos fatos, todavia, mesmo não sendo compreendidos como lógicos esses fatos estão relacionados ao cotidiano. No mesmo passo, Luis Fernando Verissimo também veio a contribuir para com a cena fantástica, iniciando na geração de 1970 ao publicar o seu primeiro livro, O Popular (1973).

Em 1998, publicou o romance O Clube dos anjos, convidado pela editora Objetiva para escrever sobre o pecado da Gula, na série Plenos Pecados. Por sua vez, em 2003, com a versão em inglês The Club ofAngels, foi eleito pela New York Public Library um dos 25 melhores livros do ano. A narrativa, que se aproxima dos romances de mistério, utilizando também artifícios como a ironia, conta a história de doze homens, dentre eles: nove assassinados, um líder supostamente assassinado, um assassino e um escritor amador que nos relata a história.

Apesar de a obra ser um romance sul-rio-grandense, o livro não apresenta marcas regionais. A cidade da narrativa não é nomeada, não possuindo nomes de ruas específicas. Pode ser qualquer cidade, desde que possua um "shopping", praças, prédios, bons restaurantes, bares e um cemitério. $\mathrm{O}$ mesmo acontece com a culinária típica do Rio Grande do Sul, o churrasco, é substituído pelo picadinho de carne, farofa com ovo e a banana frita, a qual deu origem ao nome do grupo de amigos e suas reuniões/seus jantares mensais - Clube do Picadinho.

O teor fantástico encontra-se no fato do narrador, o personagem Daniel, não possuir certeza sobre os fatos ocorridos durante a trama, deixando em aberto a possibilidade de ele ser o verdadeiro culpado pelos nove 
assassinatos e ter criado em sua imaginação o personagem Lucídio, o qual é acusado de envenenar os membros do Clube durante os jantares. Além disso, a história se passa durante nove meses e diversos flashbacks, sendo um membro assassinado de cada vez, com exceção de Paulo e Saulo que morrem no mesmo dia. Durante esses meses, somente há as suspeitas de que algo estranho acontecia durante as reuniões do Clube, pois todos seguem suas vidas como se nada fugisse da normalidade.

A obra também envolve temas como a homossexualidade e de ideologias políticas - ditadura, comunismo e capitalismo -, assuntos que permeavam o Brasil em uma determinada época e que podem ser abordagens interessantes para análises futuras da referida obra literária. O presente trabalho, por sua vez, se restringirá aos elementos bíblicos presentes na obra $\mathrm{O}$ clube dos anjos, principalmente à inversão e profanação do rito da Última Ceia e de alguns símbolos bíblicos.

\section{A Última Ceia cristã}

O caminho proposto por esse trabalho necessita de uma breve introdução sobre a Santa Ceia cristã, também conhecida como Última Ceia, a fim de compreender as simbologias presentes nesse rito.

O sociólogo Émile Durkheim em seu livro Formas elementares da vida religiosa (1989) funda a sociologia do conhecimento e alarga os estudos sobre as categorias do entendimento, que permitem compreender as maneiras de pensar em que estão associadas às práticas sociais de determinados grupos.
Entre os fenômenos que nos permitem ter acesso às "representações sociais" das mais distintas sociedades, destacam-se os ritos e os símbolos. Segundo o sociólogo, a sociedade só é possível através dos ritos e dos símbolos, uma vez que os ritos teriam a função de proporcionar a união social, ou seja, provocar, manter e renovar o sentimento de participação em grupo. Em um sentido religioso, os ritos se emancipam e passam a ser reconhecidos como forma geral de expressão da sociedade e da cultura.

A Última Ceia pode ser compreendida, conforme Durkheim (1989), como um rito positivo, um ato de comunhão, na qual há a consolidação moral de um grupo e de sua utilidade social. Visto que esse rito é executado imperativamente pela Igreja Católica a fim de recriar periodicamente um momento que representou a união de um determinado grupo, conhecido como doze apóstolos de Cristo, e a salvação de uma sociedade. No decorrer deste trabalho será possível notar a transição do rito positivo, para um rito negativo, também denominado pelo sociólogo como tabu ou profano, que, por sua vez, passa de um ato de comunhão para um ato individual. Durkheim (1989) refere-se ao rito negativo como um distanciamento, com o qual o indivíduo procura satisfazer seus próprios interesses ou necessidades nas atividades do cotidiano da vida.

Faz-se importante esclarecer que as nomenclaturas referentes à ceia que precedeu a morte de Jesus, Última Ceia e Santa Ceia, são arbitrárias e não constam no Novo Testamento bíblico. Na bíblia católica esse momento é denominado somente de ceia, 
no decorrer da história diversos líderes religiosos atribuíram em seus sermões às palavras "última e santa" a ceia. Supostamente, "Última" por tratar-se da última ceia realizada em vida por Jesus Cristo e "Santa" por referir-se a uma ação de Jesus, filho de Deus, e atribuir importância religiosa ao momento. Esse rito é celebrado pelas mais diversas religiões cristãs, tornando-se conhecido pelas duas nomenclaturas aqui mencionadas, porém outras religiões, como a Anglicana e a Presbiteriana preferem o termo "Ceia do Senhor", pois "Última” sugere que essa foi uma entre várias ceias e não dá a devida importância ao momento. Neste trabalho, utilizaremos o termo Última Ceia, por tratar-se da nomenclatura mais popular entre as religiões cristãs.

Segundo a Bíblia Sagrada ${ }^{1}$, a Última Ceia reuniu Jesus Cristo e seus doze apóstolos em Jerusalém, quando Cristo pressentiu que seria traído por um de seus apóstolos e que o apóstolo Pedro o negaria três vezes. Depois dela, Jesus é traído, preso, julgado e crucificado. Esse momento consiste em um ritual sagrado que antecede o auge do Cristianismo - Morte e Ressurreição de Jesus. Pois, para a doutrina cristã, foi através de Sua morte em auto-sacrifício e de Sua ressureição após três dias que a humanidade foi espiritualmente ressuscitada com Jesus e redimida de seus pecados diante de Deus para que "viva uma nova vida" (Romanos 6:4). Conforme o apóstolo Paulo afirmou:

\footnotetext{
${ }^{1}$ Para tal análise utilizar-se-á a bíblia católica, comumente encontrada em bancas e livrarias. Tal escolha deu-se por não ser um estudo com bases teóricas na teologia, mas apenas uma comparação com o mito cristão.
}

"Se Cristo não ressuscitou, é vã a nossa pregação, e também é vã a vossa fé." (I Coríntios 15:4), a Última Ceia antecede e prevê aquilo que consiste no alicerce das religiões cristãs.

De acordo com os Evangelhos de Marcos, Lucas, Mateus e João, Jesus teria dito na ceia que esse rito deveria ser celebrado pela posteridade, como lembrança viva de sua morte e sofrimento na cruz - tendo então se tornado o rito da comunhão eucarística, celebrado durante a missa católica. Além disso, para a religião, a comunhão representa um momento de união, partilha e fortalecimento espiritual, pois, neste momento, a hóstia é oferecida como o corpo, e o vinho como o sangue de Jesus. Como é possível notar na passagem da Última Ceia do Evangelho de Lucas:

E, tomando um pão, tendo dado graças, o partiu e lhes deu, dizendo: Isto é o meu corpo oferecido por vós; fazei isto em memória de mim. Semelhantemente, depois de cear, tomou o cálice, dizendo: Este é o cálice da nova aliança no meu sangue derramado em favor de vós. (Lc 22. 19-20).

Desde a Última Ceia, na qual Jesus Cristo prevê a traição, e durante toda a Paixão, nome dado para descrever os eventos ocorridos com Cristo antes e durante sua crucificação, a sua atitude diante aos sofrimentos e inevitável morte foi de aceitação resignada, de forma a cumprir o seu destino. Nesse sentido, supõe-se que para uma pessoa ser digna de participar da ceia católica - rito da comunhão eucarística - é preciso estar em paz espiritual, aceitar seu papel de pecador e arrepender-se, caso contrário terá que lidar 
consigo e com Deus, conforme é exposto no livro bíblico I Coríntios: "Examine-se, pois, o homem a si mesmo, e, assim, coma do pão, e beba do cálice; pois quem come e bebe sem discernir o corpo, come e bebe juízo para si." (1Co 11. 28-29).

A fim de contribuir para uma análise simbólica do rito da ceia, cabe fazer um breve comentário acerca das reflexões do teórico russo Bakhtin (1987) a respeito do banquete de Rabelais, na sua obra A cultura popular na Idade Média e no Renascimento (1987). Nesse caso, é importante ressaltar que o banquete tem um sentido mais festivo do que a ceia, que consiste basicamente na última refeição diária.

Bakhtin (1987) afirma que as imagens do banquete, isto é, do comer e do beber, estão relacionadas diretamente às festas populares e não ao comer e beber cotidianos. Elas são constituídas de um poder maior, porque estão carregadas de um caráter exageradamente alegre, de "regozijo popular". Como se fosse um ritual de celebração. A absorção do alimento não acontecia de maneira triste, ao contrário, como dito anteriormente, era alegre e triunfante. Presumia celebração, vitória ou, principalmente, término de trabalho, como na colheita ou na caça.

Nota-se que ambos os ritos, tanto a ceia quanto o banquete, representam o final de um ciclo. $O$ banquete corresponde à celebração de uma conquista e a ceia à celebração de um dia que chegou ao fim. Isso posto/Ầ vista disso, a Última Ceia assemelha-se com o banquete descrito por Bakhtin (1987), pois Jesus Cristo transforma uma ceia comum, com seus apóstolos, em um ritual de passagem e renovação que será perpetuado durante inúmeras gerações e por diferentes sociedades. Conforme descreve Bakhtin (1987), o banquete é formado por imagens que representam a celebração de um desfecho e de um recomeço:

Imagens são profundamente ativas e triunfantes, pois elas completam o processo de trabalho e de luta que o homem, vivendo em sociedade, efetua com o mundo. Elas são universais, porque têm por fundamento a abundância crescente inextinguível do princípio material. Elas são universais e misturam-se organicamente às noções de vida, morte, renascimento e renovação. Misturam-se organicamente também à ideia de verdade, livre e lúcida, que não conhece nem o medo nem a piedade, e portanto também à palavra sábia. Enfiam, penetra-as a ideia do tempo alegre, que se encaminha para um futuro melhor, que mudará e renovará tudo à sua passagem. (BAKHTIN, 1987, p. 264)

Em outras palavras, o banquete seria $o$ ato de celebração da vida. Ele possibilita o jogo com o sagrado, através da embriaguez ocasionada pelo vinho, e, de forma antagônica, também é preciso pensar em sua relação com a morte. Entretanto, a ideia não é de finitude e tristeza, pois o banquete não comporta esses sentimentos, mas sim de renovação e renascimento. Do mesmo modo que a Última Ceia antecede a morte e a ressurreição de Jesus, o momento em que é consagrado o ato da comunhão eucarística, no qual os cristãos renovam seus votos com Deus. 


\section{A última ceia do Clube do Picadinho}

Evidentemente, Verissimo traz em seu livro O Clube dos anjos uma série de referências à religião cristã, afinal o texto tem por objetivo colocar em pauta um dos sete pecados capitais instituídos pela Igreja Católicaa gula. De modo que, não por acaso, os nomes dos integrantes do Clube do Picadinho são bíblicos: Ramos, Abel, João, Marcos, Saulo, Paulo, Pedro, Tiago, Samuel, Daniel e, posteriormente, André. Lucídio é uma exceção, todavia, segundo consta no texto, "Lucídio não é um dos 117 nomes do Diabo, nem eu conjurei de qualquer profundeza para nos castigar." (VERISSIMO, 1998, p.9). Seu nome, apesar de não ser um dos nomes do Diabo, assemelha-se ao de Lúcifer, assim como também se assemelha à lucidez, qualidade que o narrador Daniel, não possui mais. Desde o início da narrativa, Daniel questiona a existência de Lucídio, podendo ele ser somente uma manifestação de sua imaginação.

No momento em que o Clube foi criado, instituiu-se que ele seria formado por dez membros, e somente por esses dez. De acordo com o dicionário de símbolos de Chevalier e Gheerbrant (2009), o número dez tem um sentido de totalidade e de criação universal, sendo um número completo "que simboliza o conjunto de lei em dez mandamentos que se resumem em um só" (p. 334). Com a morte do personagem Ramos, o grupo compreendeu que para continuar com os rituais da ceia era necessário ocupar esse espaço, que, por sua vez, foi ocupado pelo personagem André, dono de um laboratório farmacêutico e o mais rico do Clube. Contudo, a partir da crença de serem inatingíveis enquanto estivessem em grupo, a entrada de um novo membro quebrou com a totalidade e com a harmonia representada pelo numero dez. Dado que, "acrescentando-se à plenitude do 10, que simboliza um ciclo completo, o onze é um signo do excesso, da desmesura, do transbordamento, seja de que espécie for, incontinência, exagero no julgamento." (CHEVALIER e GHEERBRANT, 2009, p. 660). Desde então, o Clube desmoronara e só voltaria a sua plenitude com a chegada de um novo membro, Lucídio.

O personagem Ramos era o alicerce do Clube, após sua morte, todo encontro era motivo para desentendimento entre os membros restantes e, com isso, muitas brigas surgiram. Como, por exemplo, João, o mentiroso do grupo, "estava pensando em deixar o Clube. A reunião do Natal tinha lhe mostrado que estava na hora de parar. 'Senão vou acabar dando uma porrada em Paulo"' (VERISSIMO, 1998, p. 33). Outro motivo que desencadeou uma série de brigas nas reuniões foi a presença das mulheres. Desde o princípio do Clube foi instituído que as mulheres não poderiam participar das reuniões, umas vez que o Clube era um ambiente masculino. Na ausência de Ramos, as mulheres dos integrantes passaram a participar das reuniões, ocasionando diversos desentendimentos, como entre a mulher de Paulo e a de Abel também na reunião de Natal, destacado no trecho a seguir: "a reunião terminara com a nova mulher do Paulo e a jovem Gisela quase trocando socos" (VERISSIMO, 1998, p. 35).

Mas com a chegada de Lucídio, elas foram novamente banidas das reuniões, como se pode notar no trecho a seguir: 
Até João dizer que cortar as mulheres dos jantares tinha sido uma grande decisão. Uma sábia decisão. As mulheres eram as responsáveis pelo nosso declínio. As mulheres tinham nos arrancado do paraíso, sem elas nossos rituais readquiriam sua pureza adolescente, éramos de novo porcos contentes do bar do Alberi. (VERISSIMO, 1998, p. 53-54)

A chegada do personagem Lucídio representa a esperança de um retorno triunfante do Clube do Picadinho. De tal forma que se ele for incluído no Clube, o número de membros passa a ser doze, assim como os doze apóstolos de Cristo. Segundo o dicionário de símbolos de Chevalier e Gheerbrant (2009), doze é um número chave para o catolicismo, pois representa a Igreja triunfante, além de outros significados, como "o número de uma realização, de um ciclo concluído." (CHEVALIER; GHEERBRANT, 2009, p. 349). Desse modo, podemos dizer que com a morte de Ramos e a entrada de André em seu lugar, o Clube completa onze membros. Ou seja, há uma quebra no equilíbrio com a chegada de Lucídio, totalizando doze e representando o recomeço e o fim, pois o Clube já teria esgotado sua existência e os membros poderiam cumprir seu destino, questão que será abordada mais adiante neste trabalho.

Conforme dito anteriormente, as reuniões do Clube eram sempre ceias regadas a muita comida e muita bebida, que, por sua vez, possuíam o intuito de celebrar, principalmente, a amizade e a gastronomia, elementos que uniam seus membros. Em decorrência disso e de outras marcas que serão apontadas mais adiante, esse trabalho propõe-se a pensar as reuniões do Clube como uma grande ceia dividida em oito ceias - A última ceia do Clube do picadinho.

De acordo com os próprios membros do Clube, seus encontros constituíam-se em jantares e considerados como rituais que tinham por objetivo celebrar a vida. Nesse sentido, há uma grande aproximação com o rito da Última Ceia cristã, que também reunia doze homens e tinham por objetivo a celebração da vida, porém o Clube do picadinho celebrava de forma extravagante e egoísta. Segundo Durkheim (1989), o rito é um sistema composto por símbolos e pode ser tanto um rito positivo ou um rito negativo. O rito da Última Ceia cristã compreende-se em um rito positivo, pois representa um ato de comunhão entre seus membros e a remissão de seus pecados. Já o rito da última ceia do Clube do picadinho passa a ser um rito negativo, pois o ato de comunhão resulta na morte de seus membros pelo consumação de seus pecados.

Para que seja possível pensar no rito da Última Ceia enquanto mito, faz-se necessário compreender que, para o sociólogo Durkheim, o rito é uma ação que se realiza através de símbolos e sua atualização discursiva, o relato, pode ser concretizado através do mito. Segundo Durand (1988), o mito é uma disposição de símbolos e arquétipos que se apresenta através de mitemas, e a partir deles é possível reconhecê-lo. "Contar o mito é algo que escapa à singularidade convencional dos sistemas, compreender o mito apela para o próprio sentido do mitema. E é o que faz com que o mito seja imediatamente traduzível” (DURAND, 1988, p. 92). Ou seja, o rito da Última Ceia é tratado, na obra em análise, de forma mítica, consequentemente, 
composta por elementos que o reconheçam na trama, e esses elementos são os símbolos, como os personagens, as referências bíblicas, os jantares, o número de integrantes do Clube, dentes outros elementos que são abordados no decorrer desta análise.

A fim de compreender a possível profanação do rito da Última Ceia é importante destacar o personagem Ramos. O fundador e alicerce do Clube, apesar de falecido, ainda possui poder e importância, despertando a admiração e a idolatria dos demais membros. Durante todo o primeiro capítulo, Daniel não poupa elogios para descrever a importância de Ramos para o grupo. Foi ele quem criou o Clube, uniu-os, apresentou-lhes a boa culinária, ou seja, ao motivo de alegria em suas vidas.

Tudo começara com ele. Foi ele que transformou um dos nossos jantares normais numa solenidade, e inaugurou o Clube "com os dez que estão nesta mesa, e nunca mais do que estes dez", até que a morte ou as mulheres nos separem. Depois molhou pedaços do pão no vinho para que todos os mastigassem em conjunto e engolissem, valendo o gesto como um voto sagrado de adesão, uma cerimonia que comoveu muito ao Abel pela sua alusão eucarística. (VERISSIMO, 1998, p. 17)

$\mathrm{Na}$ citação anterior, Ramos apropria-se de palavras proferidas por Jesus Cristo na Última Ceia, dando início a profanação do rito religioso. Outra referência que aproxima Ramos de Cristo está nas primeiras páginas, nas quais Daniel explica a Lucídio como Ramos iniciou todos eles no prazer pela comida "Ele nos catequizou, pôs ordem e estilo na nossa fome.” (VERISSIMO, 1998, p. 17). Enquanto que na ceia cristã foi servido a simplicidade do pão e do vinho, na ceia do picadinho é servido a ostentação da culinária estrangeira, do vinho e do conhaque importado. A fome dos membros do Clube do Picadinho representa a Fé em Deus dos cristãos.

Segundo o dicionário de símbolos de Chevalier e Gheerbrant (2009), Ramos deriva do Domingo de Ramos, atividade religiosa que celebra a entrada de Jesus em Jerusalém, antecedendo o domingo de páscoa, ou seja, antecede a ressurreição de Cristo. Na tradição oriental, os ramos eram utilizados para aclamar os heróis e os grandes homens, simbolizando a imortalidade de sua glória. O símbolo, na obra de Verissimo, tem função antagônica, supondo que ramos simbolizava a imortalidade do Clube, e, por acaso, foi a causa da morte de oito membros, já que a morte de Daniel fica subentendida no final da narrativa.

A expressão Anno Domini, A.D, serve para designar o período depois de Cristo, popularmente conhecida como D.C. O mesmo acontece na narrativa, quando os membros se referem ao período decadente do Clube: pós-Ramos. Visto que Ramos, ao contrário de Jesus, não morreu com intuito de salvar os membros de seu Clube. Nesse sentido, do mesmo modo que Ramos significava a vida do grupo, após sua morte o Clube não tinha mais motivação para continuar com suas celebrações. Por outro lado, a chegada de Lucídio representou a ressurreição do grupo, porém, em seguida viria a significar a 
morte. Logo, pode-se dizer que o grupo nasceu e morreu com Ramos, já com Lucídio, ele ressuscitou e morreu. "Aquele seria o ano em que o Clube se reergueria da sua depressão pós-Ramos ou acabaria para sempre" (VERISSIMO, 1998, p. 28).

Daniel, o relator dessa trama, descreve o sentimento que o consumia antes de encontrar com o "salvador", sendo um sentimento de vazio e de morte. "Lucídio tinha me encontrado em meio ao naufrágio, quase submerso, só com a boca para fora, e com a loquacidade desesperada dos moribundos" (VERISSIMO, 1998, p. 19). Portanto, a narrativa extrapola o rito de passagem e abarca os ritos de nascimento/morte/ ressurreição. Recuperar a essência do Clube significava aproximar-se cada vez mais de Ramos e reencontrar um sentido para a vida vazia que levavam, conforme exposto no fragmento seguinte:

Talvez não reconquistássemos o nosso ápice, dez anos depois da benção do Ramos. Mas tínhamos chegado perto outra vez. Perto do nosso melhor momento, perto das nossas vidas perdidas, e perto do Ramos. Era isso que Abel tinha dito, em resumo. Pobre Abel. O primeiro a morrer, como na Bíblia. (VERISSIMO, 1998, p.42)

O Clube do Picadinho tem por formação homens ricos, que se conheceram ainda jovens, "éramos todos mais ou menos da mesma idade. Todos mais ou menos ricos, se bem que nossas fortunas haviam fluido e refluído em vinte anos" (VERISSIMO, 1998, p. 13). O Clube era respeitado pela sociedade local e despertava a curiosidade dos leigos e a raiva nas pessoas próximas, principalmente nas mulheres, pois elas não podiam participar das reuniões, tendo também suas opiniões a respeito do Clube ignoradas pelos membros, tal qual o narrador-personagem relata, "o Clube do Picadinho tem um longo rastro de mulheres ressentidas atrás de si" (VERISSIMO, 1998, p. 49). A esperança de continuidade, a imagem e o prestígio do grupo perante a sociedade foram resgatadas com a chegada de Lucídio ao ritual, mas logo que houve a primeira morte o grupo começara a ser desvalorizado e rechaçado novamente, porém começara a crescer e a fortalecer-se internamente, entre seus membros.

Os integrantes do Clube acreditavam que morrer após a ceia era o destino deles. Estavam fadados a pagar seus pecados morrendo após comer suas refeições favoritas, inclusive uns acreditavam que, ao invés da morte ser uma punição, estavam sendo abençoados por morrer praticando um ato de prazer. Segundo/Retomando Durkheim (1989), afirmamos que a dualidade entre o sagrado e o profano faz da religião uma realidade intelectual e os ritos fazem dela uma força moral: uma entidade que define quem está certo e recompensa e pune quem está errado. A morte do Abel foi dada como natural, o primeiro a morrer, assim como na Bíblia. Após a morte de André, o único inocente, o grupo percebeu que as mortes eram punições por seus pecados, ou um único pecado - a gula. Enquanto tentavam descobrir quais eram os pecados que atribuiriam a cada um, a morte de Abel justificava-se porque teria sido ele o único religioso do grupo e o único a abandonar a Igreja. 
Conforme mencionado em uma citação anteriormente, Abel emocionara-se ao ver Ramos proferir palavras bíblicas ao iniciar os rituais do Clube. Os demais membros não tinham religiosidade, mas compreenderam que estavam sendo punidos e que o castigo era um destino inevitável. Seja por benção ou por punição, as mortes iniciaram quando o grupo completou doze membros, significando que um ciclo havia chegado ao fim, era preciso que eles morressem para que fosse reestabelecida uma ordem. Segundo Durand (1988), o símbolo surge como reestabelecer de equilíbrios que resultam na revelação divina:

o símbolo surge como restabelecedor do equilíbrio vital comprometido pela noção da morte; depois, o símbolo é pedagogicamente utilizado para reestabelecer o equilíbrio psicossocial [...]; a simbólica estabelece um equilíbrio antropológico que constitui o humanismo ou o ecumenismo da alma humana; [...] e o símbolo resulta numa teofania. (DURAND, 1988, p. 100)

Ainda que os membros do grupo compreendessem que estavam sendo punidos por seus pecados, apesar das imagens, não havia a compreensão de que o pecado principal era a gula. Pelo contrário, morrer após degustar seus pratos preferidos era como uma dádiva, pois significava morrer de prazer. A punição de Lucídio, perde a noção de castigo e torna-se uma benção. $O$ único consciente, aquele que não aceitava morrer dessa forma, era Kid Chocolate - Tiago, mas ele não foi resistente o suficiente para negar o seu vício por chocolate. Todos os demais, exceto Abel e André, morreram conscientes que estavam comendo sua sentença de morte.

Após todos morrerem, Daniel, o único sobrevivente, acreditava que ele e Lucídio poderiam possuir um poder divino de auxiliar as pessoas a morrerem por seus prazeres. $\mathrm{O}$ personagem não conseguia, ou não queria enxergar a realidade que estava a sua frente. Pode-se pensar que há por trás dessa narrativa simbólica o que Bergson (in DURAND, 1988) chama de "função fabuladora", que se trata de um dispositivo de produção de divindades, seres imaginários, mitos e lendas, cuja função é a de proteger o indivíduo da depressão diante da morte, substituindo as lembranças reais por percepções falsas.

Supõe-se que Daniel, através de um processo de fabulação, poderia ter inventado o personagem Lucídio para aceitar o desmoronamento de sua vida e a decadência do Clube, que trazia consigo o distanciamento das suas amizades. Desde o princípio da narrativa, Daniel não sustenta a existência de Lucídio, fazendo afirmações como "preciso convencer você que não inventei o Lucídio para provar que sou inocente desses terríveis crimes" (VERISSIMO, 1998, p. 10) para direcionar o leitor e a si próprio sobre os fatos, não possuía profissão ou utilidade perante a sociedade, vivia em função do Clube e de seus caprichos sustentados pelo seu pai. A ideia de Daniel de trabalhar em conjunto com Lucídio, auxiliando as pessoas em suas mortes, daria a ele a independência financeira que nunca teve e que ele não seria mais uma vítima do Clube.

Além da função fabuladora, em que Daniel pode ter fantasiado Lucídio para 
justificar as atrocidades cometidas com o Clube em suas ceias ritualistas, há também a função de eufemização presente na narrativa. De acordo com Durand (1988), a função da imaginação "é, antes de mais nada, uma função de eufemização" (DURAND, 1998, p.101), em outras termos, a imaginação, através de outras palavras, não somente mascara a figura da morte, mas "tenta melhorar a situação do homem no mundo" (idem, p.101). Então, quer isso dizer na obra analisada que há uma inversão de valores quanto à morte $e$ às ceias do Clube, a morte não é vista como uma punição divina aos pecados cometidos pelos membros do grupo e a ceia deixa de representar um momento de comunhão, mas sim um momento de satisfação individual de cada integrante. Ou seja, o processo de eufemização ocorre no decorrer da narrativa até o final, como é possível notar na proposta realizada pelo produtor de eventos, Spector, a Daniel.

$\mathrm{Na}$ obra, diversos personagens, como o produtor de eventos, Spector, imaginam a causa da morte dos integrantes do Clube como uma "execução misericordiosa", ou ainda,"mortes clementes", "eutanásia festiva", "retirada orgiástica", "estouro final" ou "apoteose compadecida", são estes alguns eufemismos para o real significado da morte. Ou seja, os personagens, Daniel e Spector, pretendem transformar a morte em uma atividade prazerosa, "Com excesso de boa comi$\mathrm{da}$, com excesso de sexo, com excesso do que lhes desse prazer". (VERISSIMO, 1998, p. 128). Porém, a eufemização da imaginação não se restringe somente ao uso de metáforas, mas também ao uso de outras figuras semânticas, como: a hipérbole, quando Daniel descreve a sua casa comparando-a com a casa de um casal de esquilos vivendo em um tronco de madeira, assim como quando Lucídio descreve a forma como adquiriu uma escama de peixe, através de uma competição de vida ou morte em uma sociedade secreta; a antífrase, o próprio título da obra, Clube dos anjos, e a forma como alguns membros se declaravam, conforme trecho a seguir: "Aqui são todos anjos' [...] seriamos inocentes para sempre não importa o que fizéssemos" (VERISSIMO, 1998, p. 70); e a hipotipose, que a princípio não há menção na obra analisada.

Desde o início, a narrativa desperta a curiosidade do leitor. Assim o narrador-personagem, Daniel, narra como seus melhores amigos foram executados um a um. O personagem produz ambiguidade ao não deixar evidente se os fatos realmente aconteceram como ele diz, suscitando a possibilidade de tudo ser fruto de sua imaginação, como forma de fugir do que está acontecendo ao seu redor, ou resultado do vinho que está bebendo durante a escrita desse relato.

Neste caso, você pode suspeitar que sou mais do que o autor intelectual dos crimes descritos. Que meus dedos não se limitaram à sua dança tétrica nos teclados, mas também derramaram o veneno na comida, e que interferi na trama mais do que é o direito dos autores. (VERISSIMO, 1998, p. 9-10)

Ora o narrador se autopune pelos crimes - "o culpado é sempre o mesmo [...] o nome está na capa: é o autor." (VERISSIMO, 1998, p.9) -, ora denuncia o culpado, sendo Lucídio, o homem misterioso que se ofereceu 
para ser o cozinheiro dos encontros do Clube. Mas a narrativa não se restringe somente a contar a história de como esses homens foram assassinados, também versa sobre os vícios "pecaminosos" denominados pela religião Católica como os sete pecados capitais, principalmente a Gula.

Portanto, é possível perceber que não somente o pecado da gula está presente nesta narrativa, mas também os outros seis pecados capitais representados em cada personagem, uns mais que os outros.

A avareza é representada por Pedro. $\mathrm{O}$ personagem era um dos mais ricos do grupo e cheio de manias, pois fora criado pela mãe, dona Nina, e até o dia de sua morte morava com ela, conforme o narrador-personagem descreve no trecho:

Desde garotos tínhamos concedido a Pedro o direito a todos os privilégios de berço, sem nos sentirmos diminuídos. [...] Quando Pedro ganhou seu primeiro carro ao fazer dezoito anos, concordamos com suas condições de entrar no carro, só dois de cada vez para não forçar a suspenção e de sapatos limpos. [...] E quando Pedro nos apresentou a sua namorada Mara, [...] concluímos que aquilo era apenas mais um merecido premio da fortuna ao nosso príncipe herdeiro. (VERISSIMO, 1998, p. 83-84)

A luxúria é representada por Samuel, que apesar de sua aparência decadente, magro, com grandes olheiras, dentes malcuidados, fazia questão de sua aparência era o reflexo da realidade do Clube, envergado pelo fracasso e o rosto sulcado pelas promessas descumpridas. Mas ainda assim Samuel mantinha o apetite de sua juventude e o sucesso com as mulheres, nas quais ele batia durante o ato sexual. "Uma vez tínhamos sido obrigados a usar toda a nossa influência coletiva para livrar Samuel da prisão porque a mulher que ele surrara dera queixa a polícia e tinha parentes importantes." (VERISSIMO, 1998, p. 24) Contudo, Samuel não fazia sucesso somente com as mulheres, ao final da narrativa é revelado seu caso amoroso com o fundador do Clube, Ramos.

A ira, por Lucídio, o último a ingressar no Clube do picadinho. Fora amante de Ramos e mata nove integrantes do Clube, a fim de vingar a morte de seu amante, além de possuir ódio maior por Samuel, acusando-o de ter matado Ramos. "Porque Lucídio queria provar para Samuel que podia ser mais cruel do que ele. Porque a maior vingança de Lucídio não era só matar o Samuel, era matar todos os que ele amava, antes" (VERISSIMO, 1998, p. 118).

A inveja, todos a possuíam por Pedro com relação à Mara - mulher idealizada por todos eles. Nota-se que o nome Mara é desinência do nome de Maria, mulher perfeita diante dos olhos de Deus, mas que somente Pedro e Samuel possuíram. Os demais integrantes demonstram em diversos momentos inconformados com o fato de Mara ter traído Pedro logo com o pior dentre eles. Conforme trecho a seguir:

Um dia passamos a tarde inteira na agência, Marcos, Saulo e eu, discutindo como seria a mulher perfeita. [...] Mas nenhuma namorada contribui com um detalhe sequer para o nosso consenso da mulher perfeita. Naquela tarde 
descrevemos como seria o seu cabelo e sua pele e chegamos a especificar como seriam seus dentes [...] escolhemos seu timbre de voz, seios, pernas, até a espessura dos tornozelos. Só quando já estávamos com a mulher pronta, e decidindo se compartilharíamos ou disputaríamos até a morte, é que nos demos conta. Tínhamos descrito a Mara, mulher de Pedro. (VERISSIMO, 1998, p. 82)

A preguiça é representada por João, que usava seu talento para tirar dinheiro dos outros e estava sempre endividado. Uma vez foi preciso que Samuel o escondesse para que não fosse morto pelos credores,:

João só faltara às reuniões do Clube durante o tempo em que desaparecera para fugir de pessoas cujo dinheiro tinha perdido e queriam mata-lo. [...] Era um mentiroso desde garoto e usava seu talento nato para tirar dinheiro das pessoas e depois explicar por que o dinheiro desaparecera. (VERISSIMO, 1998, p. 33-34)

E, por último, o orgulho é representado por Tiago, o Kid Chocolate, que achou que poderia vencer o vício e a morte. Assim que restavam poucos membros vivos, Tiago resolveu investigar Lucídio e descobrir quem realmente era o homem misterioso que estava executando os membros do Clube. Questionado por Daniel, sobre a investigação não levar a nada, afinal "nós todos vamos morrer de qualquer jeito”, Tiago surpreendeu ao responder: "Opa. Eu não pretendo morrer tão cedo.” (VERISSIMO, 1998, p. 103).

Desse modo, a Gula é apenas o pecado principal que une os dez amigos, e em seguida
André, por convecção social, e Lucídio, o executor. Pois, assim como os doze apóstolos de Cristo não estão isentos dos pecados - Judas, o traidor, e Pedro, o que negara Jesus três vezes -, o Clube do picadinho engrandece por ostentar seus prazeres e sucumbe em seus pecados.

Há nessa narrativa, a presença de ritos, mitos e símbolos universais, como o rito mitificado da Última Ceia e os pecados capitais. Entretanto, eles sofreram uma ressignificação, afinal a Última Ceia do Clube do picadinho foi além de uma única noite, morreu, ressuscitou e morreu novamente. Enquanto que a Última Ceia cristã representava a perseverança, a comunhão e a salvação, a Última Ceia do Clube representou a profanação, na ostentação do prazer e em um suicídio coletivo, do qual estiveram isentos apenas os personagens Abel e André, que não sabiam até o momento que estavam sendo executados um a um. Segundo Durand (1998), os mitos são recontados e examinados a partir de perspectivas diferentes:

um mito nunca desaparece - ele pode adormecer, pode definhar, mas está à espera do eterno retorno (...) o mito nunca se conserva no seu estado puro. Não existe momento zero do mito, o do início absoluto. Existem inflações e deflações. É por essa razão que o mito vive, é por isso que ele é endossado por culturas, por pessoas, por momentos históricos. (DURAND, 1988, p. 111)

A obra Clube dos anjos faz parte da coleção Plenos Pecados e foi encomendada por uma editora carioca, que escolheu diferentes autores, de diferentes estados brasileiros e 
países para escrever sobre os pecados capitais. Luis Fernando Veríssimo poderia ter buscado na tradição e nos mitos gaúchos aparatos para escrever seu romance sobre $o$ pecado da Gula. Seu livro seria uma obra fortemente marcada e direcionada a um público específico, teria o objetivo de divulgar uma cultura a fim de situá-la no cenário literário brasileiro. Porém artifícios como esses não são mais necessários, foram utilizados durante muito tempo para inserir a literatura Sul-Rio-grandense no sistema literário nacional. Atualmente, escritores e obras gaúchas possuem reconhecimento sem necessariamente estarem vinculados às temáticas regionalistas.

A vida e as relações humanas no contexto contemporâneo se anunciam como objeto de representação de muitos autores gaúchos, revelando a violência, os sentimentos, o intimismo, individualismo, descoberta da identidade, crises existenciais (ZILBERMANN, 1992). Tal qual observamos na narrativa de Verissimo, que vai além da inversão do mito da última ceia. Uma obra marcada pelo fantástico, cenas cômicas e absurdas que permitiam deixar o leitor em dúvida sobre os acontecimentos, as relações homoafetivas entre os personagens, considerada um tabu, tendo em vista que optam por esconder dos amigos, a presença do suspense, caracterizado pelas mortes inexplicáveis dos integrantes do Clube do picadinho e a existência duvidosa de Lucídio, por último a discussão sobre a política nacional presente nas entrelinhas e discussões do romance.

\section{REFERÊNCIAS}

BAKHTIN, Mikhail. A cultura popular na Idade Média e no Renascimento: o contexto de François Rabelais. Trad. da Yara Frateschi Vieira. São Paulo: HUCITEC; Brasília: Ed. Da UNB, 1987.

BÍBLIA. Português. Bíblia Sagrada. Tradução: Centro Bíblico Católico. São Paulo: Edições Loyola, 1989.

CHEVALIER, Jean; GHEERBRANT, Alain. Dicionário de símbolos. Rio de Janeiro: José Olympio. 1991.

DURAND, Gilbert. As estruturas antropológicas do imaginário. Lisboa: Presença. 1989. DURAND, Gilbert. A imaginação simbólica. São Paulo: Cultrix/Editora da Universidade de São Paulo, 1988.

DURAND, Gilbert. Mito, símbolo e metodologia. Lisboa: Presença, s/d.

DURKHEIM, Émile. Formas elementares da vida religiosa. São Paulo: Paulinas, 1989.

FOUILlOUX, Danielle (et alii) Dicionário Cultural da Bíblia. Tradução de Marcos Bagno. São Paulo, Edições Loyolo: 1998

VERISSIMO, Luis Fernando. O Clube dos Anjos. Rio de Janeiro, Objetiva: 1998.

ZILBERMAN, Regina. A literatura no Rio Grande do Sul. Porto Alegre: Mercado Aberto, 1992.

Recebido para publicação em 26 out. 2015. Aceito para publicação em 08 ago. 2016. 